\title{
Znaczenie współpracy lekarza i psychologa w rehabilitacji pacjenta z szumem usznym
}

\section{Importance of physician - psychologist collaboration during tinnitus patient management}

\author{
Lucyna Karpiesz ${ }^{1,2}$, Ewelina Latkowska ${ }^{1,2}$, Izabela Sarnicka ${ }^{1,2}$, Grażyna Bartnik ${ }^{1,2}$ \\ ${ }^{1}$ Instytut Fizjologii i Patologii Słuchu, ul. Zgrupowania AK „Kampinos” 1, 01-943 Warszawa \\ ${ }^{2}$ Światowe Centrum Słuchu, ul. Mokra 17, Kajetany, 05-830 Nadarzyn
}

Adres autora: Izabela Sarnicka, Światowe Centrum Słuchu, ul. Mokra 17, Kajetany, 05-840 Nadarzyn; tel: 022 3560332, 022 3560378, 022 3560329, e-mail: i.sarnicka@ifps.org.pl

\section{Streszczenie}

W Klinice Szumów Usznych od 2004 roku stosowany jest holistyczny model leczenia szumów usznych. Zgłaszając się zatem do Kliniki pacjent zostaje objęty zarówno pomocą ze strony lekarza, jak i psychologa. W artykule autorki prezentują czynniki natury medycznej i psychologicznej, które wpływają na odczucie szumu usznego na zasadzie wzajemnego oddziaływania. Zaprezentowano schemat postępowania z pacjentem zarówno w procesie diagnostycznym, jak i dalszej rehabilitacji, który został opracowany na podstawie długoletniej wzajemnej współpracy. Temat rehabilitacji szumów usznych jest tematem otwartym. Wciąż poszukuje się takich rozwiązań, które przy zastosowaniu kilku skojarzonych metod leczenia pozwoliłyby uzyskać satysfakcjonujące efekty terapii tej dolegliwości w krótkim czasie.

Słowa kluczowe: szumy uszne • psycholog • lekarz • rehabilitacja • współpraca

\begin{abstract}
Since 2004 a complex model of tinnitus treatment has been conducted in the Tinnitus Clinic of the Institute of Physiology and Pathology of Hearing. Therefore a patient visiting the clinic receives help and support from a medical doctor and psychologist. In the present article authors describe medical and psychological factors that impact patient's perception of tinnitus, based on mutual interactions. They present diagnostic process and further rehabilitation procedures that were perfected by means of long-term cooperation between physician and psychologists. Tinnitus rehabilitation is still an open topic. Researchers, scientists are looking for treatment solutions which combined could allow us to obtain satisfactory effects of therapy within a short period of time.
\end{abstract}

Key words: tinnitus $\bullet$ psychologist $\bullet$ physycian $•$ rehabilitation $\bullet$ collaboration

\section{Wstęp}

Szum uszny jest to odczucie dźwięku lub dźwięków o różnej głośności i wysokości, często występujący w postaci ciągłej, bez mechanicznego pobudzenia ślimaka. Powstanie szumu usznego jest wynikiem nieprawidłowej aktywności nerwowej w drogach słuchowych, która jest rozpoznawana w ośrodkach słuchowych mózgu jako dźwięk. Współcześnie uważa się, że o stopniu odczuwania dokuczliwości szumu decyduje nie miejsce generacji szumu (czyli źródło zmiany w uchu, które spowodowało nieprawidłową aktywność nerwową), ale to, jakie reakcje wywołuje ten bodziec w naszym systemie nerwowym. Dodatkowo podkreśla się, że w proces odczuwania szumu włączone są poza układem słuchowym również takie układy jak układ limbiczny (odpowiedzialny za emocje) oraz autonomiczny układ nerwowy (odpowiedzialny za reakcje obronne). Powyższe założenie jest podstawą terapii Tinnitus Retraining Therapy (TRT) opracowanej przez Pawła Jastreboffa [zob. Bartnik G., 2010; s.79].

Bardzo ważnym i podstawowym etapem w leczeniu szumu usznego jest wykonanie pełnej diagnostyki medycznej. Od jej wyników zależy bowiem jaki rodzaj terapii i postępowania zostanie zaproponowany pacjentowi. Na tym etapie w pewnych przypadkach wskazane jest włączenie diagnozy psychologicznej, która dokonuje oceny stanu psychicznego pacjenta oraz rozszerza wywiad o czynniki natury psychologicznej wpływające na odczucie szumu usznego. Po zakończeniu etapu diagnostycznego i podjęciu wynikających z niego pierwszych decyzji i działań natury medycznej, kolejnym etapem jest rehabilitacja pacjenta z szumem usznym. Podstawowym celem w leczeniu szumów usznych jest habituacja szumu 
czyli zmniejszenie lub zniesienie jego percepcji w centralnych ośrodkach słuchowych. Habituacja opiera się na podstawach neurofizjologii układu nerwowego. Wykorzystuje takie cechy naszego mózgu jak plastyczność i zdolność do filtrowania niektórych sygnałów [zob. red. Skarżyński H., 2000, s. 48]

Współcześnie obowiązują dwa główne podejścia do zjawiska szumu usznego, które odnoszą się do procesu habituacji [Bartnik G., 2010]. Pierwszym z nich jest podejście psychologiczne oparte na modelu „kognitywno-behawioralnym”, zapoczątkowanym przez profesora Hallama w 1984roku [Hallam R.S. i wsp., 1984]. Zdaniem profesora Hallama szum uszny jako drażniący bodziec jest wynikiem dyshabituacji. Naturalny proces habituacji może być przerwany przez: nadanie szumom negatywnego znaczenia emocjonalnego oraz pobudzenie autonomicznego układu nerwowego na skutek pojawienia się szumu lub na skutek innego źródła stresu. Dążenie do ponownej habituacji ma polegać na świadomych procesach zmiany reakcji poznawczej i emocjonalnej w kontekście szumu oraz wprowadzeniu licznych kontrolowanych zachowań pozwalających na opanowanie negatywnych reakcji i emocji związanych z szumem. Drugim podejściem jest model neurofizjologiczny autorstwa profesora Jastreboffa [Jastreboff P.J, 1990]. Podkreśla on rolę mechanicznych odruchów odbywających się na poziomie podkorowym (poza naszą świadomością) zarówno w procesie rozwoju szumu, jak i w procesie jego habituacji. Odnosi się do mechanizmu filtrowania przez nasz mózg informacji. Informacje nieistotne są odrzucane, a tym samym nie są uświadamiane; z kolei informacje, które nabierają znaczenia emocjonalnego lub są oceniane jako niebezpieczne, czy nowe, nie są odfiltrowywane i ulegają uświadomieniu. Decyzja, czy dźwięk jest ważny czy nie, odbywa się na poziomie podkorowym układu nerwowego. Do tego, aby bodziec stał się obojętny i nieuświadamiany ma doprowadzić zastosowanie metody Tinnitus Retraining Therapy (TRT), która oparta jest na modelu neurofizjologicznym polegającym na niwelowaniu negatywnych skojarzeń związanych z szumem i łagodzi jego percepcję w korze mózgowej.

Dwa zaprezentowane powyżej podejścia: model psychologiczny i neurofizjologiczny mają zarówno wspólne cechy, a przede wszystkim wspólny cel, którym jest dążenie do habituacji szumu usznego oraz uznanie roli Centralnego Układu Nerwowego (CUN) w odczuwaniu dokuczliwości szumu, jak i różnice, np. w podejściu dotyczącym mechanizmów uczestniczących w procesie rozwoju zjawiska szumu na poziomie świadomym i nieświadomym [Bartnik G., 2010]. Ze względu na wspólny cel istnieje możliwość połączenia tych dwóch rodzajów terapii wykorzystujących w dążeniu do habituacji modyfikację procesów podkorowych i korowych, czyli TRT i metody psychologiczne. Różnice między podejściem neurofizjologicznym (TRT) i psychologicznym umożliwiają ich wzajemne uzupełnianie się poprzez wpływ na sferę nieświadomości i świadomości pacjenta. W Klinice Szumów Usznych te dwa podejścia reprezentowane przez lekarzy i psychologów są stosowane równolegle i wzajemnie uzupełniają się dzięki współpracy: lekarz - psycholog.

\section{Współpraca lekarza i psychologa na etapie diagnostycznym}

Szum uszny jest zjawiskiem subiektywnym, którego poziom odczuwania nie zawsze zależy od parametrów audiologicznych. Często w doświadczeniu klinicznym obserwuje się, że mimo podobieństwa głośności i wysokości dźwięku u dwóch różnych pacjentów, odczucie szumu może być bardzo różne. Jeden $z$ nich nie może sobie poradzić z szumem, który drażni i przeszkadza w funkcjonowaniu, drugi odczuwa szum tylko w sytuacji absolutnej ciszy i jest wobec niego obojętny. Tę prawidłowość (brak korelacji między parametrami audiologicznymi a dokuczliwością szumu) potwierdzają liczne badania [Reed G.F., 1960; House J.W., 1981; Henry J.L., Wilson P.H., 1995]. W związku z tym nasuwa się wniosek, że istnieją pewne dodatkowe czynniki, poza parametrami audiologicznymi, które wpływają na odbiór szumu. Mogą to być czynniki z różnych obszarów funkcjonowania człowieka: medycznego (np. nieleczone nadciśnienie tętnicze), środowiskowego (np. hałas w otoczeniu), psychologicznego (np. podatność na czynniki stresogenne, pobudzenie organizmu, bezsenność).

W badaniu przyczyn pojawienia się szumu usznego, jego ewaluacji, czy zmienności jego odczuwania, wskazane jest zatem rozszerzone podejście diagnostyczne polegające na uwzględnieniu nie tylko diagnostyki medycznej, ale również sprawdzające ogólny stan kondycji psychofizycznej pacjenta. Pierwszym i najważniejszym elementem w diagnostyce pacjenta z szumem usznym jest pogłębiony wywiad. Umożliwia on zdobycie istotnych informacji dotyczących przyczyn szumu, jego charakteru oraz okoliczności, w jakich szum się zmienia [Fabijańska A. i wsp., 1997]. Dodatkowo $\mathrm{w}$ wywiadzie uwzględnia się, w jaki sposób pacjent ocenia stopień świadomości i dokuczliwości szumu oraz jego wpływ na funkcjonowanie w życiu codziennym. Kolejnym obszarem, na który lekarz powinien zwrócić szczególną uwagę są choroby ogólnoustrojowe (nadciśnienie tętnicze, zaburzenia hormonalne tarczycy, alergia, cukrzyca, choroba wieńcowa serca, zmiany w szyjnym odcinku kręgosłupa, anemia i inne), czynniki środowiskowe, które negatywnie mogą wpływać na narząd słuchu (narażenie na hałas, narażenie na czynniki stresogenne) oraz czynniki genetyczne (wywiad rodzinny). Szum może być jednym z objawów chorób z zakresu otolaryngologii, często współwystępuje też z niedosłuchem o różnym stopniu głębokości. [zob. Bartnik G., 2010]. Każdy pacjent, który zgłasza się do Kliniki Szumów Usznych ma przeprowadzoną pełną diagnostykę otorynolaryngologiczną celem wykluczenia patologii ucha wymagającej leczenia operacyjnego. Po wykonaniu mikro-videootoskopowej oceny uszu i zbadaniu nosogardła, lekarz kieruje pacjenta na badania audiologiczne, które dają możliwość wykluczenia zmian w drodze słuchowej i oceny poziomu słyszenia u pacjenta. Przeprowadzone badania dają podstawę do podjęcia decyzji dotyczącej dalszych interwencji medycznych oraz wskazują na ewentualną potrzebę przeprowadzenia dalszych badań obrazowych i otoneurologicznych.

Jeżeli w wywiadzie lekarskim pojawiają się informacje świadczące o nasilaniu się szumu w sytuacjach stresogennych, narażeniu na przewlekły lub ostry stres, objawach psychosomatycznych o niestwierdzonej przyczynie w organizmie, niekorzystnej zmianie samopoczucia, nastawienia lub zachowania, wówczas lekarz kieruje pacjenta na konsultację psychologiczną - jako rozszerzenie i uzupełnienie diagnostyki. Jeżeli te elementy zostaną pominięte na etapie diagnozy, może to rzutować na przyszłe efekty 
terapii. Postępy w leczeniu będą bowiem utrudnione z powodu ciągłego oddziaływania tych czynników na objaw szumu. W literaturze podkreśla się następujące czynniki związane ze sferą psychologicznego funkcjonowania, które warto wziąć pod uwagę podczas diagnozy oraz rehabilitacji szumu usznego:

- tendencje depresyjne i lękowe lub trwająca depresja i zaburzenie lękowe - osoby, które doświadczają dokuczliwego szumu usznego jednocześnie częściej wykazują tendencje do reagowania depresją i lękiem [Halford J.B.S. i Anderson S.D., 1991; Andersson G. i Vretblad P., 2000; Zöger S. i wsp., 2001];

- nadmierne skupienie uwagi na objawach somatycznych z organizmu i towarzyszący temu niepokój - Andersson (2002) w swojej publikacji przedstawia szereg badań wskazujących na zależność między zwiększonym niepokojem dotyczącym objawów z organizmu a niepokojem związanym z odczuciem szumu usznego;

- rozdrażnienie, napięcie, frustracja, pobudzenie z powodu obecności szumu lub sytuacji stresogennych, objawy psychosomatyczne, gromadzenie emocji negatywnych - osoby z szumem często zgłaszają występowanie negatywnych odczuć emocjonalnych, które kumulują się również w organizmie w postaci somatycznych objawów [Tyler R.S i Baker L.J., 1983; Kotyło P. i wsp., 2006]. Dodatkowo badania przeprowadzone w Klinice Szumów Usznych w Instytucie Fizjologii i Patologii Słuchu wskazują na znacznie wyższy stopień tłumienia emocji negatywnych u osób z szumem usznym w porównaniu $\mathrm{z}$ uśrednionym wynikiem $\mathrm{w}$ badaniach nad populacją polską. Różnice te są szczególnie widoczne między uśrednionym wynikiem w badaniach nad populacją polską a pacjentami, którzy oceniają szum jako bardzo dokuczliwy. [Sarnicka I. i wsp., 2009];

- problemy ze snem i trudności w odpoczynku - są to najczęściej zgłaszane problemy przez osoby z szumem usznym. W badaniach nad tym zjawiskiem zwykle około 70\% osób badanych zgłaszało problemy ze snem [Tyler R.S. i Baker L.J., 1983; Andersson G., Lyttkens L., Larsen H.C., 1999; Kotyło P. i wsp., 2006];

- problemy z koncentracją występujące w postaci trudności z podzielnością i utrzymaniem uwagi, wydłużonego czasu reakcji [Tyler R.S i Baker L.J., 1983; Andersson G. i wsp., 2000; Rossiter S. i wsp. 2006].

W wywiadzie w trakcie konsultacji psychologicznej uwzględnia się również czynniki natury poznawczej takie jak: błędne schematy poznawcze, negatywne skojarzenia, które mogą wpływać na nasilenie reakcji emocjonalnej na szum oraz częstsze skupianie się na dolegliwości. Szczególną uwagę poświęca się również trudnościom w psychicznej akceptacji niedosłuchu i przewidywanym trudnościom w akceptacji aparatu słuchowego.

\section{Współpraca lekarza i psychologa na etapie rehabilitacji}

Metodą, którą efektywnie wykorzystuje się w leczeniu pacjentów z szumem usznym, jest metoda Tinnitus Retraining Therapy (TRT). Cechuje ją wysoka efektywność przekraczająca $80 \%$, przy czym proces leczenia bywa długotrwały i często trwa ponad dwa lata [Bartnik G.. i wsp., 2003]. Dlatego poszukuje się rozwiązań, które przy zastosowaniu połączonych kilku metod pozwoliłyby uzyskać satysfakcjonujące efekty terapii w krótszym czasie. Jedną $\mathrm{z}$ takich metod, której zastosowanie można rozważać łącznie z terapią TRT, jest terapia psychologiczna.

G. Bartnik [zob. Bartnik G., 2010, s.80] wskazuje na następujące zadania, jakie stoją przed prowadzącymi TRT: „Głównym zadaniem prowadzącego TRT jest wydostanie pacjenta $\mathrm{z}$ mechanizmu błędnego koła. Prowadzi to do zniwelowania jakichkolwiek negatywnych reakcji i asocjacji związanych z szumem, a tym samym ułatwia habituację wrażenia szumu usznego, tzn. zmniejszenie lub nawet zniesienie jego percepcji w korze mózgowej. Do tych celów wiodą dwie równoległe drogi postępowania: a) konsultacje terapeutyczne oraz b) trening dźwiękiem. Należy przy tym podkreślić, że te dwie drogi wzajemnie się uzupełniają i są ze sobą nierozerwalnie związane. O ile w pewnych przypadkach można uzyskać pozytywny efekt terapeutyczny tylko dzięki konsultacjom, o tyle stosowanie samego treningu dźwiękiem jest zawsze błędem w sztuce”.

Konsultacje terapeutyczne dzielimy na konsultację główną i konsultacje kontrolne. Podczas konsultacji głównej lekarz zapoznaje pacjenta $\mathrm{z}$ wynikami przeprowadzonych badań diagnostycznych, wyjaśnia ewentualną przyczynę i miejsce generacji szumu. Wyjaśnienie pacjentowi w przystępny sposób patomechanizmu szumu i charakteru tego zjawiska powoduje często "odmitologizowanie" szumu i uspokojenie pacjenta. Ważnym elementem konsultacji jest wytłumaczenie pacjentowi zasad terapii TRT oraz zaproponowanie terapii dźwiękowej przy użyciu najbardziej odpowiedniego w danym przypadku urządzenia. Przebieg i charakter konsultacji głównej ma charakter indywidualny i zależy w dużej mierze od uzyskanych wyników badań i od kondycji pacjenta. Po konsultacji głównej część pacjentów również odbywa wizytę u psychologa. Celem tej wizyty jest ocena stanu psychicznego pacjenta, omówienie czynników psychologicznych wpływających na odczucie szumu, omówienie zasad terapii dźwiękowej opartej na aktywnym odbiorze dźwięków, omówienie zasad odwracania uwagi od dolegliwości. W zależności od oceny stanu psychicznego pacjenta podejmowana jest decyzja odnośnie stałych konsultacji psychologicznych, psychoterapii, uczestnictwa w grupowej terapii psychologicznej.

Na konsultacjach kontrolnych u lekarza, których częstotliwość zależy od indywidualnych potrzeb pacjenta [zob. Bartnik G.., 2010, s.85], lekarz ocenia wspólnie z pacjentem efekty uzyskane od ostatniej wizyty, uzupełnia brakujące informacje, koryguje ewentualne błędy w stosowaniu się do zaleceń, omawia czynniki ryzyka, które mają wpływ na szum uszny i zleca kontrolne badania audiologiczne.

Celem dalszych konsultacji psychologicznych jest zmniejszenie objawów nerwicowych, jakie powstały w związku z pojawieniem się szumów usznych oraz zneutralizowanie reakcji emocjonalnych na szum. Oddziaływanie psychologiczne często dotyczy również błędnych schematów myślenia, które wytworzyły się w wyniku szumu oraz złagodzenia efektów stresu i pobudzenia organizmu.

Kolejną, równoległą do konsultacji terapeutycznych formą oddziaływania jest terapia dźwiękiem. Dźwięk w terapii TRT ma na celu zmniejszenie kontrastu w drogach słuchowych pomiędzy szumem a tłem otoczenia. Stosuje 
się tutaj różnego rodzaju urządzenia dostosowane indywidualnie do pacjenta. Są to: generatory szumu szerokopasmowego, generatory stacjonarne i inne urządzenia elektryczne emitujące odpowiednie tło dźwiękowe. U pacjentów z niedosłuchem do treningu słuchowego używa się odpowiedniego tła akustycznego otoczenia wzmocnionego przez aparaty słuchowe [Skarżyński H., 2000]. Trening dźwiękowy w ramach terapii TRT stosowany jest w sposób bierny, czyli pacjent nie powinien świadomie skupiać się na dźwięku, a stosować go tylko jako stałe tło akustyczne. Jest to szczególnie ważne w ciszy.

Równolegle do terapii dźwiękiem w ramach TRT proponowane są oddziaływania psychologiczne, które wspomagają proces habituacji szumu poprzez uczenie świadomego przestawiania uwagi na bodźce zewnętrzne. W ćwiczeniach, które pomagają $\mathrm{w}$ kształtowaniu pozytywnych reakcji na dźwięki, wykorzystuje się tło dźwiękowe w formie zajęć z muzykoterapii i zajęć relaksacyjnych. Ćwiczenia te najczęściej proponowane są w ramach terapii grupowej, która odbywa się w formie hospitalizacji rehabilitacyjnych. Kwalifikacja na tego typu hospitalizację odbywa się przy pełnej współpracy lekarza i psychologa (pacjent powinien spełniać określone kryteria zdrowotne i wykazywać pewne predyspozycje osobowościowe). Mechanizm tego rodzaju terapii polega głównie na oddziaływaniu procesu grupowego. Zajęcia prowadzone są według ogólnie przyjętych zasad terapii krótkoterminowej [Ellis A., 2000]. Dzielą się na trzy bloki tematyczne: (1) terapia oddziaływań grupowych, (2) terapia aktywizująca $\mathrm{z}$ wykorzystaniem dźwięków, (3) terapia relaksacyjna. Dodatkową zaletą tych zajęć są regularne spotkania pacjentów w grupie, co umożliwia wymianę doświadczeń związanych z szumami usznymi.

\section{Wnioski}

Dokuczliwość szumów usznych bardzo często wynika z wielu czynników, zarówno natury medycznej jak i psychologicznej. Pominięcie jednego z tych obszarów może spowodować fragmentaryczne spojrzenie na problem. Natomiast połączenie informacji medycznych i psychologicznych o pacjencie daje możliwość całościowego spojrzenia na jego sytuację i rozszerza pole działania w rehabilitacji. Również wymiana tych informacji między psychologiem i lekarzem pomaga w zrozumieniu potrzeb pacjenta i adekwatnym kierunku oddziaływania w postępowaniu leczniczym. Zastosowanie TRT wspólnie z terapią psychologiczną przynosi ulgę wielu cierpiącym pacjentom już po krótkim okresie leczenia.

\section{Piśmiennictwo:}

1. Andersson G.: Psychological aspects of tinnitus and the application of cognitive-behavioral therapy. Clin Psychol Rev, 2002; 22: 977-90

2. Andersson G., Ericsson J., Lundh L., Lyttkens L.: Tinnitus and cognitive interference: a Stroop Paradigm study. J Speech Lan Hear Res, 2000; 43: 1168-73

3. Andersson G., Lyttkens L., Larsen H.C.: Distinguishing levels of tinnitus distress. Clin Otolaryngol Allied Sci, 1999; 24: 404-10

4. Andersson G., Vretblad P.: Anxiety sensitivity in patients with chronic tinnitus. Scandinavian Journal of Behaviour Therapy, 2000; 29(2): 57-64

5. Bartnik G.., Fabijańska A., Raj-Koziak D. i wsp.: Wyniki habituacji szumów usznych i nadwrażliwości słuchowej metodą Tinnitus Retraining Therapy. Otorynolaryngologia, 2003; 2(2): 83-89

6. Bartnik G.: Szumy uszne i nadwrażliwość słuchowa. Warszawa: Instytut Fizjologii i Patologii Słuchu, 2010

7. Ellis A.: Terapia krótkoterminowa. Lepiej, głębiej, trwalej. Gdańskie Wydawnictwo Psychologiczne, Gdańsk, 2000

8. Fabijańska A., Bartnik G., Jastreboff P.J. i wsp.: Wstępny wywiad z pacjentem cierpiącym na szumy uszne. Audiofonologia, 1997; XI: 205-9

9. Halford J.B.S., Anderson S.D.: Anxiety and depression in tinnitus sufferers. J Psychosom Res, 1991; 35(4/5): 383-90

10. Hallam R.S., Rachman S., Hinchcliffe R.: Psychological aspects of tinnitus. (W:): Rachman S. (red.) Contribution to medical Psychology. Oxford: Pergamon Press, 1984; 3: 31-34

11. Henry J.L., Wilson P.H.: The Psychological Management of Chronic Tinnitus. A Cognitive-Behavioral Approach. Boston: Allyn and Bacon, 2001
12. Henry J.L., Wilson P.H.: Coping with tinnitus: Two studies of psychological and audiological characterstics of patients with high and low tinnitus-related distress. Int Tinnitus J, 1995; 1: 85-92

13. Jastreboff P.J.: Phantom auditory perception (tinnitus): mechanism of generation and perception. Neurosci Res, 1990; 8: 221-54

14. Kotyło P., Merecz D., Niebudek-Bogusz E., Śliwińska-Kowalska M: Program oceny I interwencji psychologicznej u pacjentów z szumami usznymi. Otolaryngologia, 2006; 5(4): 189-94

15. Reed G.F.: An audiometric study of 200 cases of subjective tinnitus. Archives of Otolaryngology, 1960; 71: 94-104

16. Rossiter S., Stevens C., Walker G.: Tinnitus and its effect on working memory and attention. J Speech Lang Hear Res, 2006; 49: $150-60$

17. Sarnicka I., Fludra M., Latkowska E. i wsp.: Charakterystyka psychologiczna pacjentów z szumami usznymi na podtawie Inwentarza Osobowości NEO-FFI oraz wybranych narzędzi pomiaru w psychologii zdrowia. (W:) Człowiek chory. Aspekty biopsychospołeczne. Lublin, 2009; 2: 115-24

18. Skarżyński H. (red.).: Szumy uszne w życiu codziennym. Porady praktyczne dla pacjentów. Warszawa: IFPS, 200

19. Tyler R.S., Baker L.J.: Difficulties experienced by tinnitus sufferers. J Speech Hear Disord, 1983; 48: 150-54

20. Zöger S., Holgers K.M., Svedlund J.: Psychiatric disorders in tinnitus patients without severe hearing impairment: 24 month follow-up of patients at an audiological clinic, Audiology, 2001; 40: $133-40$ 